University of Nebraska - Lincoln

DigitalCommons@University of Nebraska - Lincoln

Publications, Agencies and Staff of the U.S.

Department of Commerce

U.S. Department of Commerce

2012

\title{
Effect of fires on soil organic carbon pool and mineralization in a Northeastern China wetland
}

Hongmei Zhao

Chinese Academy of Sciences, zhaohongmei@neigae.ac.cn

Daniel Q. Tong

U.S. NOAA Air Resources Laboratory, daniel.tong@noaa.gov

Qianxin Lin

Louisiana State University, comlin@lsu.edu

Xianguo Lu

Chinese Academy of Sciences, luxg@neigae.ac.cn

Guoping Wang

Chinese Academy of Sciences, wangguoping@neigae.ac.cn

Follow this and additional works at: https://digitalcommons.unl.edu/usdeptcommercepub

Part of the Environmental Sciences Commons

Zhao, Hongmei; Tong, Daniel Q.; Lin, Qianxin; Lu, Xianguo; and Wang, Guoping, "Effect of fires on soil organic carbon pool and mineralization in a Northeastern China wetland" (2012). Publications, Agencies and Staff of the U.S. Department of Commerce. 424.

https://digitalcommons.unl.edu/usdeptcommercepub/424

This Article is brought to you for free and open access by the U.S. Department of Commerce at DigitalCommons@University of Nebraska - Lincoln. It has been accepted for inclusion in Publications, Agencies and Staff of the U.S. Department of Commerce by an authorized administrator of DigitalCommons@University of Nebraska - Lincoln. 


\title{
Effect of fires on soil organic carbon pool and mineralization in a Northeastern China wetland
}

\author{
Hongmei Zhao a , Daniel Q. Tong a,b, Qianxin Lin ${ }^{\mathrm{a}, \mathrm{c}}$, Xianguo Lu ${ }^{\mathrm{a}}$, Guoping Wang ${ }^{\mathrm{a}, *}$

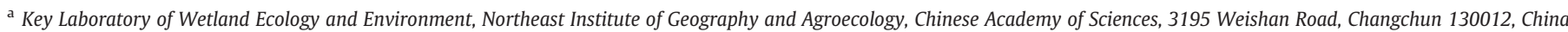 \\ b U.S. NOAA Air Resources Laboratory, Silver Spring, MD 20910, USA \\ c Department of Oceanography and Coastal Sciences, School of the Coast E Environment, Louisiana State University, Baton Rouge, LA 70803, USA
}

\section{A R T I C L E I N F O}

\section{Article history:}

Received 8 August 2011

Received in revised form 26 March 2012

Accepted 12 May 2012

Available online 18 August 2012

\section{Keywords:}

Carbon cycling

Soil carbon

Wetland

Fire

Mineralization

Microbial biomass carbon

\begin{abstract}
A B S T R A C T
Fire occurs frequently over wetland, but little is known of its impact on soil carbon variations and carbon mineralization, process that are potentially important in global carbon cycle. To investigate this issue, we have designed and implemented a two-year field campaign to quality the effects of fire seasonality and frequency on soil carbon abundance and carbon mineralization in a wetland of the Sanjiang Plain in Northeastern China. A total of 4 burning experiments were conducted over 12 wetland plots from autumn 2007 to spring 2009. Our results show that after burning soil organic carbon (OC) increased in the burned soils during the first two growing seasons. Fire effects on dissolved organic carbon (DOC) and microbial biomass carbon (MBC), however, were more subtle. During the first post-burning growing season, the levels of DOC and MBC were higher than in the unburned soil. The increase however was temporary, and there was no significant difference between the burned and unburned soils in the second growing season. Carbon mineralization rate increased after burning, and $\mathrm{CO}_{2}$ emission rates were higher from burned soils than from unburned soils. Our findings suggest that burning increased $\mathrm{CO}_{2}$ emission to the atmosphere not only during the combustion process, but also through biogeochemical processes in an extended post-burning period.
\end{abstract}

(c) 2012 Elsevier B.V. All rights reserved.

\section{Introduction}

Fires exert multiple levels of effects on the earth system through regulating nutrient cycling in ecosystems (Knicker, 2007; Smith, 1983), and emitting climate-forcing gases and aerosols into the atmosphere (Wiedinymer et al., 2006). Fire activities are controlled by many environmental factors, including regional climate change that has been linked to an increased number of large wildfires (Westerling et al., 2007). A myriad of gases and aerosols, including carbon dioxide $\left(\mathrm{CO}_{2}\right)$, oxides of nitrogen $\left(\mathrm{NO}_{\mathrm{x}}\right)$, and black carbon $(\mathrm{BC})$ are emitted into the atmosphere during fire events (Wiedinymer et al., 2006). Emissions of these gases and aerosols can degrade air quality and form unhealthy levels of smog and inhalable fine particles. Fire also intervenes with the cycling of nutrients in ecosystems. It has been reported that fires can substantially alter carbon cycling in forest (Hatten and Zabowski, 2009; Palese et al., 2004) and grassland (Bremer and Ham, 2010; Oluwole, et al., 2008).

Abbreviations: OC, organic carbon; DOC, dissolved organic carbon; $\mathrm{MBC}$, microbial biomass carbon.

* Corresponding author. Tel.: + 86431 85542339; fax: + 8643185542298.

E-mail addresses: zhaohongmei@neigae.ac.cn (H. Zhao), daniel.tong@noaa.gov

(D.Q. Tong), comlin@lsu.edu (Q. Lin), luxg@neigae.ac.cn (X. Lu), wangguoping@neigae.ac.cn (G. Wang).
In the global carbon cycle, fire is estimated to cause 2-4 Pg carbon to be emitted into the atmosphere each year (van der Werf et al., 2006). Yet, emissions of biomass burning only reflect one aspect of the fire and carbon dynamics. The long-term impact of fires on the ecosystem-atmosphere carbon exchange is more complicated, depending on several biogeochemical processes such as the carbon accumulation and release in plants and soils after fire (Houghton et al., 2000; Kaye et al., 2010). Soil organic carbon is one of the largest carbon pools on the earth's surface, accounting for $2344 \mathrm{Pg}$ of overall global carbon (Jobbagy and Jackson, 2000). Fire affects soil organic matter content not only at the time of burning but also during post-burning period (Fernández et al., 1999). Many previous studies have compared a number of environmental variables before and after burning, but little is known about the evolution of these variables with time after burning. Furthermore, seasonal patterns of soil carbon changes have not been reported before due to the difficulty to collect long-term data. In this study we report the results of a two-year consecutive observation of how fires affect carbon cycling in a Sanjiang Plain wetland in the Northeastern China.

The Sanjiang Plain is one of the largest freshwater marshes in China. This region is unique in that it has experienced intensive cultivation over the past 50 years, in which prescribed burning has been frequently used to reclaim land in order to feed a rapidly growing population. Originally, crop residues over the converted cropland are used for fuel during cooking and heating. With more rural families in China switching to 
cleaner fuels, agricultural residues are increasingly being burned in the field after harvesting (Li et al., 2007). The agricultural burning in the Northeastern China peaks in April and October. These fires over agricultural lands are frequently spread into wetland, especially in Calamagrostis angustifolia wetland, producing a seasonal fire activity pattern similar to that over farmland. Compared to other well-studied ecosystems, few studies have previously investigated the effects of fire on nutrient dynamics in the wetland ecosystems (Gu et al., 2008; Qian et al., 2009). The results from this study will provide further information to reveal the behavior of carbon cycling in response to fires through a series of carefully designed experiments.

The objective of this study is to investigate the temporal variations of soil carbon content and carbon mineralization rate in response to different fire seasonality, frequencies, and severity in the Sanjiang Plain wetland. Fire not only perturbs the level of soil organic carbon (OC), but also redistributes different labile fractions of organic carbon, such as dissolved organic carbon (DOC) and microbial biomass carbon (MBC). The labile fractions of organic carbon can respond rapidly to changes in carbon supply (Zhang et al., 2007). In addition, some researchers have observed that there was a noticeable amount of carbon mineralization after burning, due to the release of soluble organics from microbial biomass (Choromanska and DeLuca, 2002). Recognizing the complex effects of fire on soil OC, we conducted a two-year field campaign to study: (1) the effects of fire on soil OC, DOC and MBC; (2) change in carbon mineralization rate after fire; (3) the effects of burning time, burning frequency and time-since-burning on the soil carbon pool. In particular, we tested the hypotheses that fires will reduce the levels of soil OC, DOC and MBC, but increase the carbon mineralization rate. We also examined if the burning time and frequency could affect carbon cycling in wetland soils.

\section{Materials and methods}

\subsection{Study site}

The burning experiments were conducted over the Sanjiang Plain in Northeastern China $\left(47^{\circ} 35^{\prime} \mathrm{N}, 133^{\circ} 38^{\prime} \mathrm{E}\right)$. The Sanjiang Plain is an alluvial plain formed by three major rivers, namely, the Heiron River, the Songhua River, and the Wusuli River, in this region. The annual average of temperature over this region ranges from 1.9 to $3.9^{\circ} \mathrm{C}$ and the annual rainfall varies from 500 to $650 \mathrm{~mm}$ (Wang et al., 2006). The low altitude, flat topography, and inductive climate conditions make it one of the largest wetlands in China (Wang et al., 2006). The entire region was historically a contiguous wetland, but is currently fragmented into different hydrological units by the agriculture land and canals. The Sanjiang wetland covers an area of about $9069 \mathrm{~km}^{2}$ (Wang et al., 2002) of depressional and riparian wetlands. The major soil types in this region are marsh soil. We conducted the experiments in a depressional wetland. In the depressional wetland, from the edge to the center, there are $C$. angustifolia, Carex lasiocarpa, Carex pseudo-curaica, Carex meyeriana, and Carex appendiculata, respectively (Zhao, 1999). In a typical wetland plant community over this region, C. angustifolia is the dominant plant species. In Sanjiang Plain wetlands, $C$. angustifolia was once estimated to cover approximately $150.6 \times 10^{4} \mathrm{hm}^{2}$, and account for $13.8 \%$ of the total land surface over the Sanjiang Plain (Zhou, 2005). C. angustifolia are mostly spread at the edges of the depressional or riparian wetlands, making it prone to the effects of fire burning than other species during agricultural residue burning or wildfires. In order to emulate the natural fire in Sanjiang Plain wetland, we choose $C$. angustifolia as our object.

\subsection{Design of experiments}

In this study nine blocks over a depressional wetland were selected to examine the fire effect on soil carbon content. These blocks include three for autumn burnings, three for spring burnings, and three for reference (undisturbed). Each block was further divided into three contiguous plots for fire treatment with different burning frequencies. From 2007 to 2009, eight experiments were performed over these plots to compare the effect of: 1 ) burning time (autumn vs. spring burning), 2) burning frequency (burning once vs. twice), and 3) post-burning period (immediately after burning and one year after burning) on soil carbon and carbon mineralization. Each treatment was repeated in three rectangular plots with an area of $150 \mathrm{~m}^{2}(10 \times 15 \mathrm{~m})$, and a spacing of $5 \mathrm{~m}$ between two plots. The two burnt treatments had two burning frequencies. The autumn burnings were conducted in early October of 2007 and 2008. Spring burnings were conducted in April of 2008 and 2009, respectively. The details of the on-set of prescribed burnings and pre- and postfire samplings are depicted in Fig. 1.

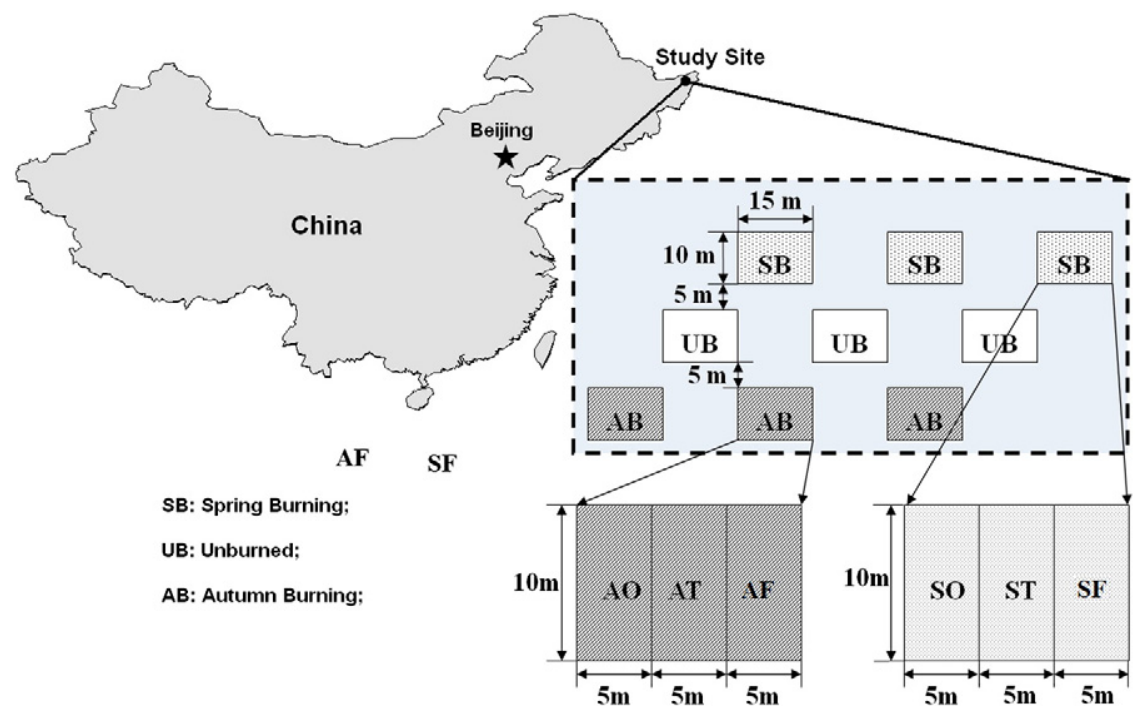

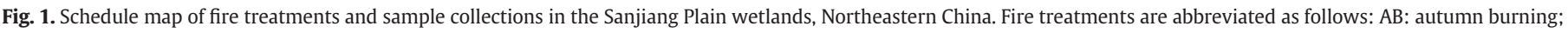

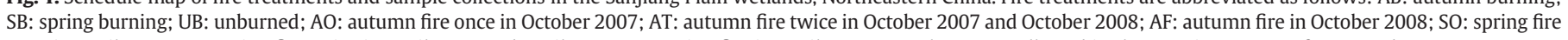
once in April 2008; ST: spring fire twice in April 2008 and April 2009; SF: spring fire in April 2009. Samples were collected in the growing season of 2008 and 2009. 


\subsection{Sampling and carbon analysis}

For wetland plants such as $C$. angustifolia wetlands, the highest density of grass root is generally found in the top $15 \mathrm{~cm}$ soil layer. Hence, the carbon contents in this grass root layer were more responsive to the effects of imposed fires. Six soil samples of $15 \mathrm{~cm}$ deep were collected for each experiment treatment: two soil samples per plot, each soil sample consisting of three cores $2.5 \mathrm{~cm}$ in diameter in the center of the plot, and each burning treatment with 3 plots. Soil samples were immediately transported to the laboratory, passed through 2-mm sieves and stored at $4{ }^{\circ} \mathrm{C}$ temperature until being analyzed. Dissolved organic carbon was estimated by extracting $20 \mathrm{~g}$ oven-dry equivalents of field-moist soil samples in $100 \mathrm{~mL}$ distilled water $(1: 5 \mathrm{w} / \mathrm{v})$ in a $150 \mathrm{~mL}$ polypropylene bottlers, and shaken for $30 \mathrm{~min}$ on a shaker. Soil-water suspensions were centrifuged and the supernatants were filtered through a $0.45 \mu \mathrm{m}$ filter into separate vials for analysis. The DOC content was determined with a TOC- $\mathrm{V}_{\mathrm{CPH}}$ (Shimadzu, Japan) (Jones and Willett, 2006).

Microbial biomass carbon was determined by the chloroformfumigation extraction method as described by Lu (2000) and Vance et al. (1987). The procedure was conducted on $10 \mathrm{~g}$ oven-dry equivalents of field-moist soil samples. The non-fumigated samples were immediately extracted with $0.5 \mathrm{~mol} \mathrm{~L}^{-1} \quad \mathrm{~K}_{2} \mathrm{SO}_{4}(1: 4$, w/v) for $30 \mathrm{~min}$ on a shaker. The fumigated samples were placed in a vacuum desiccator with a beaker containing $50 \mathrm{~mL}$ ethanol-free chloroform. The desiccator was evacuated until the chloroform had boiled for $2 \mathrm{~min}$. The desiccator was then sealed and incubated for $24 \mathrm{~h}$ in the dark. Then the beaker of chloroform was removed and the desiccator evacuated to remove all traces of chloroform from the soils. The fumigated soils were extracted with $0.5 \mathrm{~mol} \mathrm{~L}^{-1} \mathrm{~K}_{2} \mathrm{SO}_{4}$ under the same conditions as the non-fumigated samples. The carbon content of the $\mathrm{K}_{2} \mathrm{SO}_{4}$ extracts was measured on TOC- $\mathrm{V}_{\mathrm{CPH}}$ (Shimadzu, Japan). The amount of $\mathrm{MBC}$ was then calculated from the difference in extractable organic carbon between fumigated and unfumigated soil samples using the following formula:

$\mathrm{MBC}=E_{C} / 0.38$.

Where $E_{C}$ is the difference in extractable organic carbon between the fumigated and unfumigated treatments; 0.38 is the efficiency of extraction constant (Lu, 2000; Vance et al., 1987). Here the unit of $\mathrm{MBC}$ content was $\mathrm{mg} \mathrm{kg}^{-1}$.

Soil organic carbon was determined using external heating potassium dichromate oxidation method (Lu, 2000). Approximately $0.1 \mathrm{~g}$ air-dry soil samples (processed through $0.178-\mathrm{mm}$ sieves) were transferred to flasks with $5 \mathrm{~mL}$ of $0.8 \mathrm{~mol} \mathrm{~L}^{-1} \mathrm{~K}_{2} \mathrm{Cr}_{2} \mathrm{O}_{7}$, and with $5 \mathrm{~mL} \mathrm{H}_{2} \mathrm{SO}_{4}$ gradually added. The flasks and contents were then heated on the sand bath, the sample digested until the solution boiling for $5 \mathrm{~min}$. The flask was then removed from the sand bath and allowed to cool thoroughly. Then the sample was titrated with $0.2 \mathrm{~mol} \mathrm{~L}^{-1}$ $\mathrm{FeSO}_{4}$ to determine the amount of carbon mineralization. The carbon contents (\%) were then calculated as the following formula:

Carbon $=\left(V_{0}-V\right) \times C \times 0.003 \times 1.08 \times 100 / W$.

Where $V_{0}$ was the amount of $\mathrm{FeSO}_{4}$ consumed by the reference; $V$ was the amount of $\mathrm{FeSO}_{4}$ consumed by the samples; 1.08 was the oxidation correction factor; $W$ was the mass of air-dry soil.

\subsection{Carbon mineralization}

The intent of carbon mineralization was investigated using the alkali absorption method (Bridgham et al., 1998; Yang, 2006). Fieldmoist samples, equivalent of $20 \mathrm{~g}$ oven-dry soil mass, were passed through 2-mm sieves, and placed into a $500 \mathrm{~mL}$ canning jar filled with $50 \mathrm{~mL}$ distilled water. An open-top plastic pot containing $5 \mathrm{~mL}$ of $1 \mathrm{~mol} \mathrm{~L}^{-1} \mathrm{NaOH}$ solution was put into each canning jar. The soil samples were incubated in the canning jar with closed lids under room temperature (approximately $28^{\circ} \mathrm{C}$ ). The total incubation period was 31 days, during which samples were analyzed on the 2nd, 4th, 8th, 12th, 18th, 24th and 31st days. At each measurement time, the plastic pot was removed, and the solution inside was titrated to determine the amount of $\mathrm{CO}_{2}$ release. The amount of $\mathrm{CO}_{2}$ release (expressed in $\mathrm{mg} \mathrm{C} / \mathrm{g}$ ) was then calculated as the following formula:

$\mathrm{CO}_{2}-C=\frac{\left(V_{0}-V\right) \times C}{2} \times 44 \times \frac{12}{44} \times \frac{1}{m \times(1-a)}$

Where $V_{0}$ was the amount of HCL consumed by the reference; $V$ was the amount of HCL consumed by the samples; $C$ was the concentration of HCL; $m$ was the mass of air-dry soil; $a$ was the soil moisture.

\subsection{Statistical analyses}

Statistical analyses were conducted using SPSS 11.5. An analysis of variance (ANOVA) was used to evaluate the effects of prescribed burning on OC, DOC, and MBC. One-way ANOVA was conducted for each sample data separately. Two-way ANOVA test was carried out for the effects of burning and sampling time on OC, DOC and MBC. In addition, Levene's test was employed to test for homogeneity of variances. Finally, we conducted least-significant-difference (LSD) test to determine the significant differences among paired treatments. The LSD test is a method for comparing treatment group means.

\section{Results and discussions}

\subsection{Effects of fire on soil organic carbon}

Our measurements showed that fires increased the content of soil organic carbon in the first and second growing seasons after the burning (Fig. 2). Compared to that in the unburned plots, the OC contents in the autumn burning and spring burning soil samples increased by $44 \%$ and $60 \%$, respectively. The ANOVA test showed that there was a significant effect of burning on OC contents during the whole sampling period $(p<0.05)$. The finding that soil OC increased significantly after fire in this study was consistent with the results from studies conducted elsewhere (e.g., Kara and Bolat, 2009; Pardini et al., 2004). The increase is largely due to increased aboveground

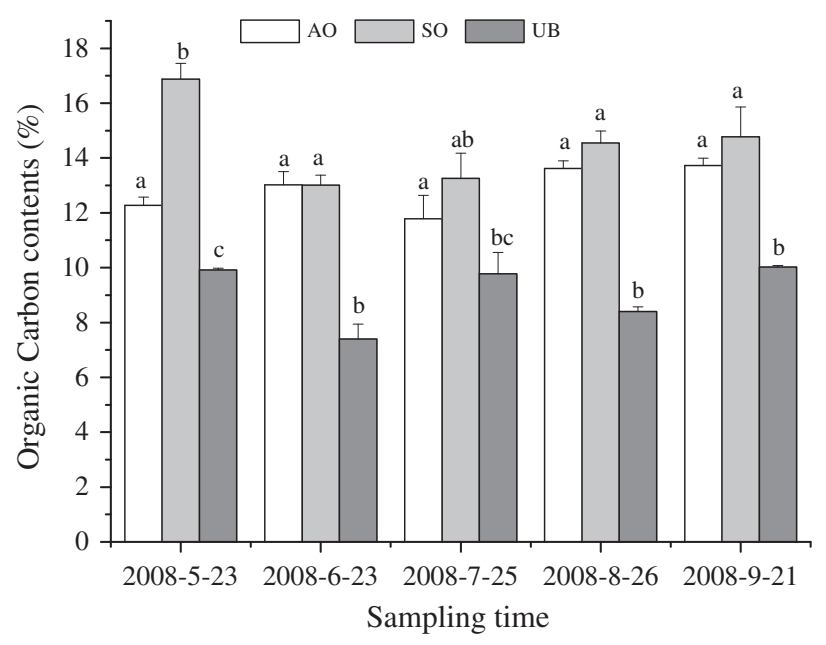

Fig. 2. Effects of prescribed fire on soil organic carbon in the first growing season after fire in 2008. Values represent means $\pm S E(n=6)$; Different letters ( $a, b, c$ etc.) indicated that the means were statistically different from each other; Abbreviations for fire treatments are given in Fig.1; Sampling time was from May to September in 2008. 
production and very fine roots of grasses that may have passed through sieve in fire treatment soils (Ansley et al., 2006).

The timing and frequency of burning also affected the OC abundance in the soil. In our experiments, fires have been ignited in both spring and autumn time. The timing of burning resulted in different levels of perturbation in soil OC. During the first post-fire growing season, spring burned plots showed the largest increase in soil OC content in May 2008, approximately twice as large as the change in autumn burned plots (Fig. 2). The difference between soil OC in spring- and autumn-burn plots became smaller in the second year, but the soil OC remained higher in the spring burned plots than in autumn burned or unburned plots (Fig. 3). The spring burning, ignited in April 2008, was only one month before the beginning of soil sampling, while the autumn burning in October 2007 was six months before the sampling. Averaged over the five sampled months (MaySeptember), the concentration of soil OC in the spring burned plots was elevated by $28 \%$ compared to that in unburned plots, while in the autumn burned plots soil OC content was elevated by $27 \%$. Several previous studies have reported similar results that spring burnings had a greater effect on soil OC than autumn burnings (e.g., Hatten et al., 2008). The autumn burned soils had a lower OC content than the spring burning soils, likely due to litter burned and soil organic matter consumption by snowmelt and wind erosion during the winter period from burning to sampling time (Hatten et al., 2008). For the spring burning, litter could be decomposed and incorporated into the soil by soil fauna. For the autumn burning, however, the soil surface is left partly uncovered during the winter period, resulting in loss of surface soil and litter through snowmelt and wind erosion (Knicker, 2007).

Our results also showed that although fire can increase wetland soil OC immediately after the burning, the fire effect diminished with time. Monleon et al. (1997) observed an increase in mineral soil nitrogen content immediately after fire, but a subsequent return to the pre-burning level in a few years. To investigate if such a trend exists for soil organic carbon, we further sampled and measured soil OC in the second growing season (June, July and September 2009). We found that the OC content in burned soil remained significantly higher than in the unburned soil during the second postburning growing season (Fig. 3), regardless of the burning time and burning frequency (once or twice). The difference in soil OC level between burned and unburned plots, however, became smaller in the second post-fire growing year than in the first year. In addition, during the second growing season, however, in soil OC between the

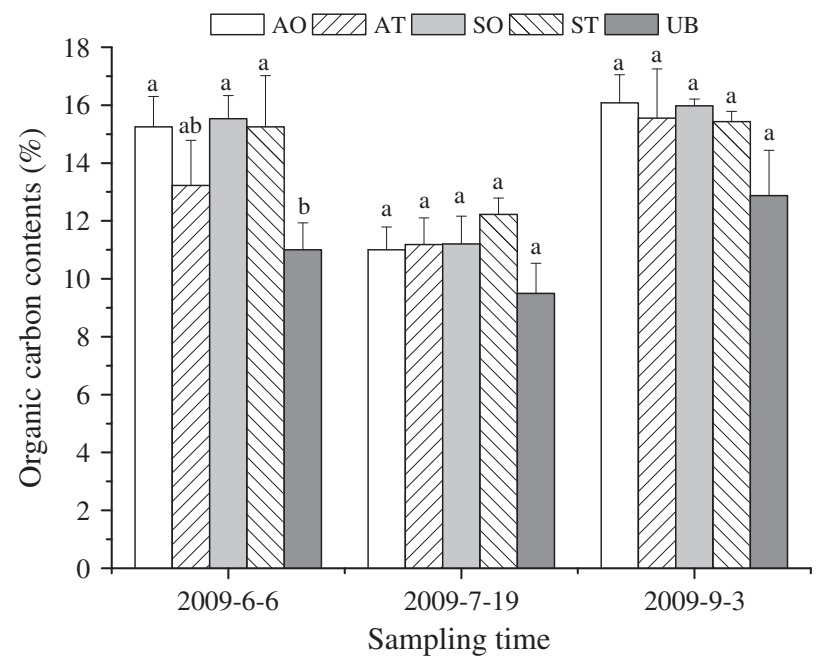

Fig. 3. Effects of prescribed fire on soil organic carbon in the second growing season after fire in 2009. Values represent means $\pm S E(n=6)$; Different letters (a, b, c etc) indicated that the means were statistically different from each other; Abbreviations for fire treatments are given in Fig.1; Sampling time was from June to September in 2009.
Table 1

Repeated-measure analysis (ANOVA) of organic carbon (OC), dissolved organic carbon (DOC) and microbial biomass carbon (MBC) content in wetland soils for data collected in 2008 .

\begin{tabular}{|c|c|c|c|c|c|c|}
\hline \multirow{2}{*}{$\begin{array}{l}\text { Source of } \\
\text { variation }\end{array}$} & \multicolumn{2}{|l|}{ OC } & \multicolumn{2}{|l|}{ DOC } & \multicolumn{2}{|l|}{$\mathrm{MBC}$} \\
\hline & $\mathrm{F}$ & $p$ & $\mathrm{~F}$ & $p$ & $\mathrm{~F}$ & $p$ \\
\hline Burn & 98.699 & .000 & 14.163 & .000 & 8.797 & .001 \\
\hline Time & 5.197 & .002 & 32.528 & .000 & 8.802 & .000 \\
\hline Burn $\times$ time & 3.799 & .003 & 2.135 & .058 & .697 & .691 \\
\hline
\end{tabular}

spring and autumn fire treatments became smaller, consistent with the overall diminishing effect of fire on soil OC perturbation.

Fig. 3 also revealed that burning frequency affects soil OC abundance. During the study period, double burning (a second fire ignited one year after the first one) yielded lower soil OC than single fire treatment in the second growing season, except in July. For the July samples, soil with double treatments contained more OC than that with single treatment. During the sampling period, the soil OC content increased by $20 \%$ and $29 \%$ in plots burned twice in autumn and spring, respectively, compared to that in the unburned plots. Both the burning time and the sampling time had a significant effect on soil OC contents $(p<0.05$, Table 1$)$. More frequent burning and greater fire severity led to the increase of soil OC due to the increased surface biomass and underground carbon pool from dead roots (Czimczik et al., 2005; Oluwole et al., 2008).

\subsection{Effects of fire on dissolved organic carbon}

Similar to the response in soil OC, DOC concentrations in burned soils increased in the first post-fire growing season (Fig. 4). The DOC contents in autumn burned and spring burned soils ranged from 45.3 to $91.2 \mathrm{mg} \mathrm{kg}^{-1}$ and from 50.7 to $106.2 \mathrm{mg} \mathrm{kg}^{-1}$, respectively, while in unburned soils the DOC concentrations ranged from 31.1 to $80.5 \mathrm{mg} \mathrm{kg}^{-1}$. The ANOVA test showed that the effect of prescribed burning on DOC concentrations was significant $(p<0.05)$. In the second growing season after burning, however, the effects of prescribed burning on DOC became insignificant $(p>0.05)$ (Fig. 5). During the two-year sampling period, the DOC content reached its maximum in May. Compared to autumn burnings, spring burnings exerted a larger effect on DOC contents in May. Burning time and sampling time had significant effects on soil DOC contents $(p<0.05)$, but the interaction between burning and sampling time on soil DOC was insignificant $(p>0.05$, Table 1$)$.

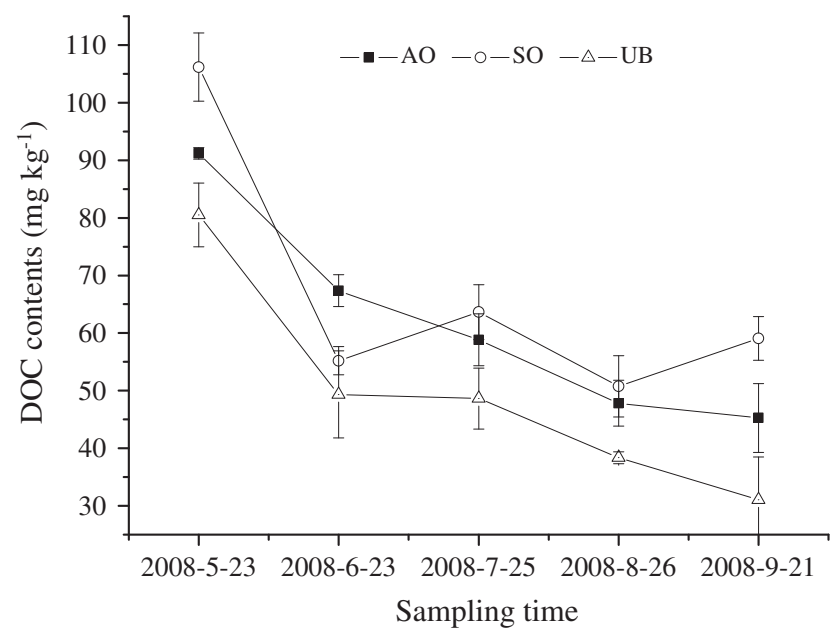

Fig. 4. Effects of prescribed fire on dissolved organic carbon in the first growing season after fire in 2008. Values represent means $\pm S E(n=6)$; Abbreviations for fire treatments are given in Fig. 1; Sampling time was from May to September in 2008. 


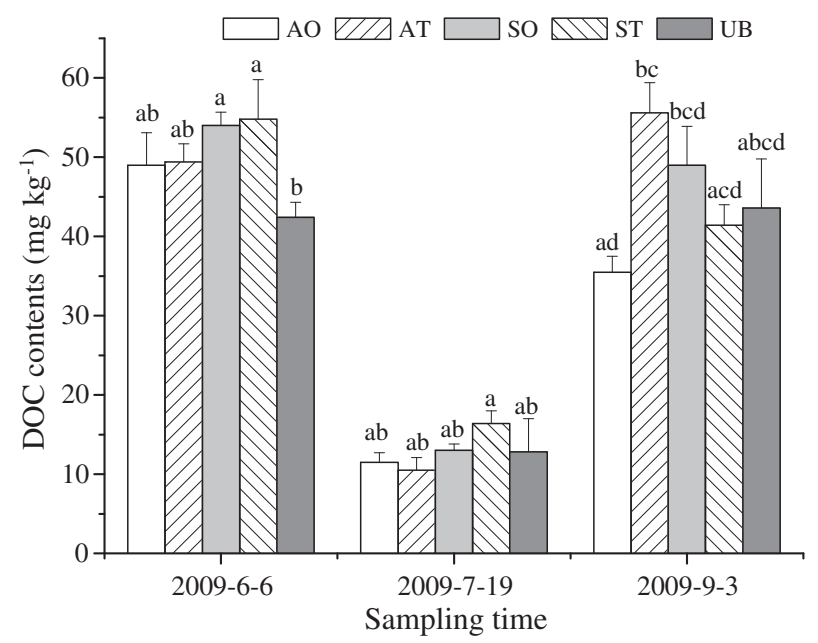

Fig. 5. Effects of prescribed fire on dissolved organic carbon in the second growing season after fire in 2009. Values represent means $\pm S E(n=6)$; Different letters ( $a, b, c$ etc) indicated that the means were statistically different from each other; Abbreviations for fire treatments are given in Fig. 1; Sampling time was from June to September in 2009.

Compared to the unburned soils, the DOC contents in the burned soils were elevated but only for a short period. A previous study showed soil organic matter content, carbon to nitrogen ratio, $\mathrm{pH}$ values, and nutrient availability all increased after burning (e.g., Badía and Martí, 2003), which led to increase in microbial activity and leaching of DOC (Andersson et al., 2004; Jokinen et al., 2006). In another study, however, Shibata et al. (2003) found that fires significantly reduced the DOC concentration in the surface moss layer compared to that in the unburned site one month after the burning, due in part to soluble organic carbon loss after ignition. In our study, the DOC contents were larger in the burned soils in the first year after burning, but there was no significant difference in the second year. A short-lived peak DOC concentration in soil water after burning was also observed by Clay et al. (2009), who also found that the DOC content was not significantly elevated one year after the burning of a blanket bog in USA.

During the two-year sampling period, the soil DOC content was at peak in May in both burned and unburned plots. The DOC peak in May is attributed to the decomposition of microorganism and snow leaching in winter (Yang, 2006). Compared to the autumn burnings, the spring burnings produced higher DOC contents in May because of the addition of plant ashes and less exposure to water and wind erosions between burning and sampling. The DOC contents in freshly burned ashes were about $140.4 \pm 45.9 \mathrm{mg} \mathrm{kg}^{-1}$, which was well above the typical soil DOC level in this region (Zhao et al., 2010). The addition of ashes would therefore increase DOC in the burned soils. The lag between burning and sampling affected the DOC level because the ashes left on the surface soil can be removed by wind lifting and/or water erosion and the longer the lag is, the more ashes will be removed. The autumn burned plots were particularly subject to this influence as the snowmelt and strong wind in winter and spring over the Northeastern China were effective to remove the ashes from the soil surface. Consequently, the soil DOC contents were lower in the autumn burned plots than in the spring burned ones.

\subsection{Effects of fire on microbial biomass carbon}

The effect of fires on the content of MBC is similar to that of DOC, with a significant increase in soil MBC in the first post-fire year, but a considerably smaller change in the second year. In the first postburning growing season, the MBC contents in the burned soils were greater than that in the unburned soils (Fig. 6). Soil MBC in the autumn burned and spring burned soils increased by $28.4 \%$ and $33.2 \%$,

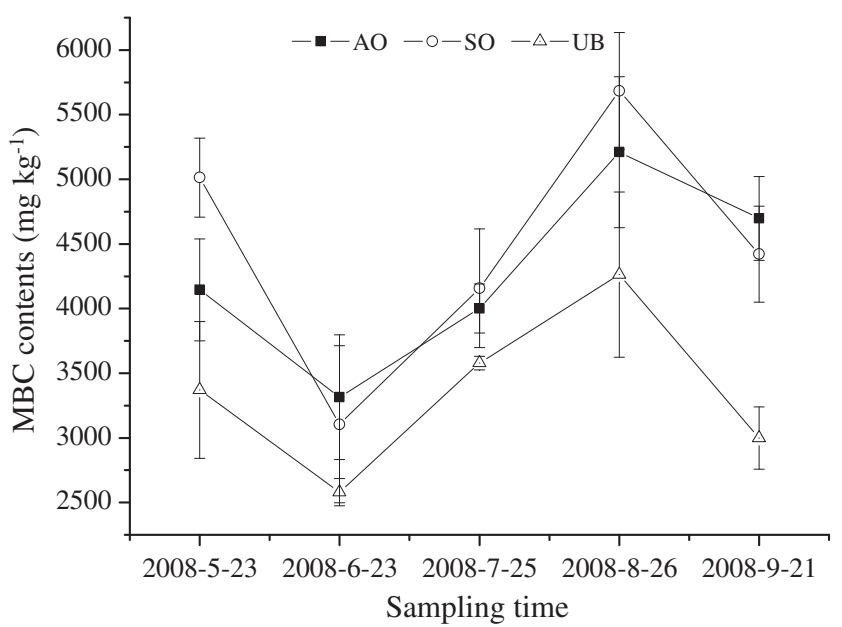

Fig. 6. Effects of prescribed fire on microbial biomass carbon in the first growing season after fire in 2008. Values represent means $\pm S E(n=6)$; Abbreviations for fire treatments are given in Fig. 1; Sampling time was from May to September in 2008.

respectively, from the level in the unburned soils. During the sampled period, the largest increase was found in September, in which the MBC contents were enriched by $56.6 \%$ and $47.4 \%$ in the autumn and spring burned soils, respectively. The ANOVA test showed that the effect of fires on soil MBC was significant $(p<0.05)$.

After the first post-burning year, the effect of burning became insignificant (Fig. 7). In the second year, the ANOVA test showed that there was no noticeable difference between the burned and unburned soils $(p>0.05)$. The MBC contents in the burned soils remained higher, but the magnitude of $\mathrm{MBC}$ monthly variations was comparable to that in the unburned soils. During the second growing season, the MBC contents were higher in May and August and lower in June and September, different from that in the first year. Therefore, the timing of sample collections imposed a significant effect on the determined content of MBC $(p<0.05)$, but the interaction between burning time and sampling time on soil DOC was not significant (Table 1 ).

Our finding that fires significantly increased soil MBC in the first post-fire growing season was in accordance with the results from others (Liu et al., 2010; Rutigliano et al., 2007). Higher availability of organic carbon, as suggested by the positive correlation between $\mathrm{MBC}$ and $\mathrm{OC}$, was partially responsible for higher $\mathrm{MBC}$ after burning.

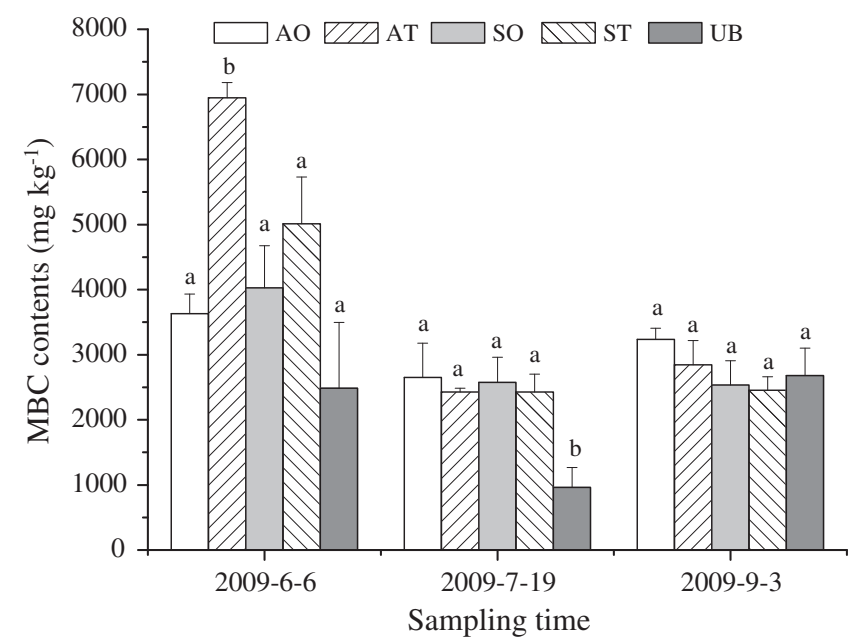

Fig. 7. Effects of prescribed fire on microbial biomass carbon in the second growing season after fire in 2009. Values represent means $\pm S E(n=6)$. Different letters (a, b etc) indicated that the means were statistically different from each other; Abbreviations for fire treatments are given in Fig. 1; Sampling time was from June to September in 2009. 
In addition, the growth of surviving microorganisms could be enhanced through the use of the "recycled" nutrients contained in the ashes (Snyman, 2003) and labile organic carbon and ammonium $\left(\mathrm{NH}_{4}^{+}\right)$released from microorganisms destroyed by heat (Andersson et al., 2004). The fire impacts became less significant when the extra ash input was consumed, which was shown by the lack of significant difference of MBC contents between burned and unburned soils in the second post-burning growing season.

Our results also showed that burning frequency had no considerable effect on soil MBC. This result is accordance with Kara and Bolat (2009) who also found no significant differences in MBC between the burned and unburned soils. In other studies, however, it was reported that soil MBC was reduced after burning (Harris et al., 2008; Palese et al., 2004), because of decreased above-ground litter, lower burning intensity, and cold and rainy weather over these study areas. Similarly, Choromanska and DeLuca (2002) observed that repeated burning can diminish $\mathrm{MBC}$ relative to soils that have been only burnt once. In this study, the soil MBC increased after burning even though the increase was temporary, and the effects of burning on MBC varied with the burning frequency and the lag between burning and sampling. The different responses in the MBC variations between present and the previous studies were likely caused by several interlaced factors, including fire frequency and severity, soil surface conditions (wetland here vs. forest elsewhere), soil OC change, and prevailing weather conditions. For instance, in one of the burning experiments we found that the lower burning intensity resulted in a considerable lower above-ground litter in the second year. Besides affecting the litter accumulation, fire intensity can also play important roles in determining the survival of microbial community after the burning. Compared to forest floor, the Sanjiang wetland was typically associated with very high soil moisture due to the constant presence of water/snow at the surface. The high moisture and low fuel loading in wetland could prevent the microbial community from the penetrating damages of the fires, ensuring a higher survival rate than in forest. Meanwhile, the moist soil and sufficient litter deposition formed favorable conditions to facilitate fast microbial growth in the post-fire growing season. The MBC contents peaked in the first post-fire growing season, and then declined in the second year, a behavior correlated with the soil OC variation.

The $\mathrm{MBC} / \mathrm{OC}$ ratio, as a soil quality indicator, was a useful measure to monitor soil organic carbon and provided a more sensitive index than organic carbon alone in burning impacted soil. Generally, if a soil is being degraded, the MBC pool will decline at a faster rate than organic matter, and the $\mathrm{MBC} / \mathrm{OC}$ ratio will decrease as well (Anderson, 2003; Kara and Bolat, 2007). In this study, our data showed that the $\mathrm{MBC}$ abundance was positively related to that of OC. Meanwhile, the $\mathrm{MBC} / \mathrm{OC}$ ratios were significantly lower in the burned soils than in the unburned soils $(p<0.05)$, which was consistent with the results from Kara and Bolat (2009). Our results confirmed the earlier observation that based on the change of the carbon pools, there was degradation in soil quality immediately following burning.

\subsection{Effect of fire on carbon mineralization}

Compared to that in the unburned soils, the total amount of mineralized carbon increased significantly in the burned soils (Fig. 8). The results showed that burning time played an important role in regulating cumulative carbon mineralization. Spring fires affected the mineralized carbon content by a larger magnitude than autumn fires; consistent with the response of soil OC and MBC. Burning frequency also had a noticeable effect on carbon mineralization. For the autumn burns, the mineralized carbon content in the burned once and twice soils increased by $213 \%$ and $117 \%$, respectively, compared to that in the unburned soils. The ANOVA test showed that there was a significant difference among the autumn burns $(p<0.05)$. For the spring

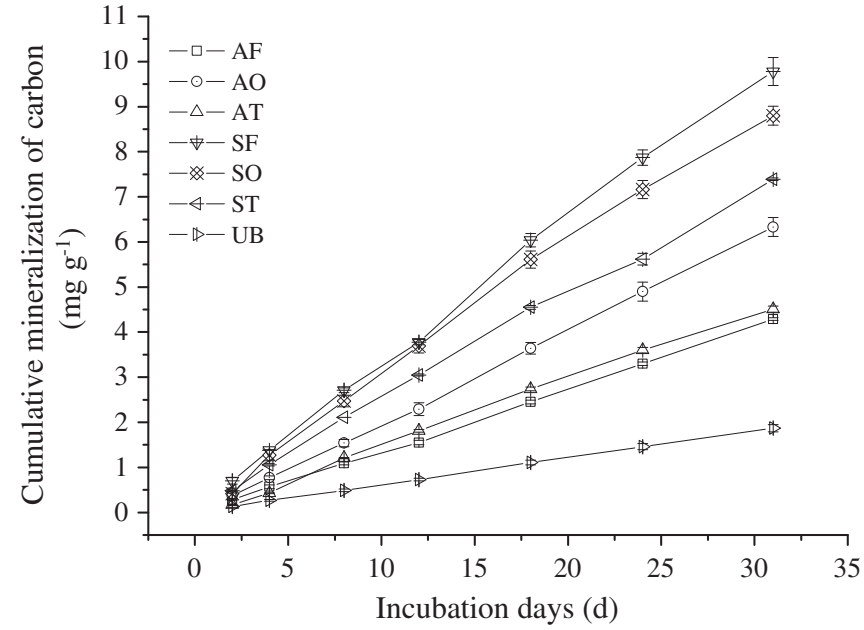

Fig. 8. Effects of prescribed fire on carbon mineralization. Values represent means $\pm \mathrm{SE}$ $(n=6)$; Abbreviations for fire treatments are given in Fig. 1.

burn, the mineralized carbon content in the burned once and twice soils was greater than unburned soils by $367 \%$ and $300 \%$, respectively. ANOVA results showed that there was a significant difference among the spring burned soils $(p<0.01)$. The carbon mineralization rates also increased significantly after burning. The spring and autumn burned soils had higher carbon mineralization rates, which were about 4.7 and 2.6 times faster than the corresponding ones in the unburned soils, respectively. During the incubation period, the carbon mineralization rates decreased with the increasing incubation days, due to the diminishing availability of the adequate carbon sources.

The significant increase in carbon mineralization rate after the prescribed burnings in this study indicated higher carbon dioxide emissions rom the unburned wetland than commanded by the undisturbed seasonal variability. The short-term increase in carbon mineralization rate was attributed to the increased organic carbon and nitrogen contents in the burned soils, as well as an improved quality of substrate for microbial growth and a possible increase in labile compounds, all of which stimulated microbial growth (Hatten and Zabowski, 2009; Rutigliano et al., 2007). Furthermore, burning could decrease the efficiency of carbon conservation by soil microflora (Fierror et al., 2007). Overall, fires increased the microbial metabolism in the post-burning soil through influencing both abiotic soil properties and soil microbial composition and activity. In most fire-impacted ecosystems, soil moisture is a key regulating factor for soil respiration (Gupta and Singh, 1981). This is not the case for the wetland ecosystem. The expanded decomposable carbon pool in the post-fire wetland can increase the emission fluxes of carbon dioxides from vegetation respiration and photosynthesis, similar to that observed by Ward et al. (2007). Consequently, the burnings over the wetland caused more carbon losses from the burned soils than the unburned ecosystems. Higher $\mathrm{CO}_{2}$ emissions from burned soils compared to unburned soils have also been reported in many studies (Knapp et al., 1998; Rutigliano et al., 2007; Ward et al., 2007). Therefore, burning increased $\mathrm{CO}_{2}$ emissions into the atmosphere not only during combustion processes but also for an extended period after the burning.

During the incubation period, spring burnings had a larger effect on carbon mineralization than the autumn burnings. During the spring burnings, the soil surface was covered by water from snowmelt (an average depth of $5 \mathrm{~cm}$ ). The presence of water reduced the fire severity and carbon mineralization (Hatten and Zabowski, 2009). Another contributing factor that caused the higher carbon mineralization in spring burning plot is the time between burning and sampling. The samples for autumn burnings were collected five months after the burning, while the samples for the spring burning immediately after the burning. The longer lag in autumn burning 


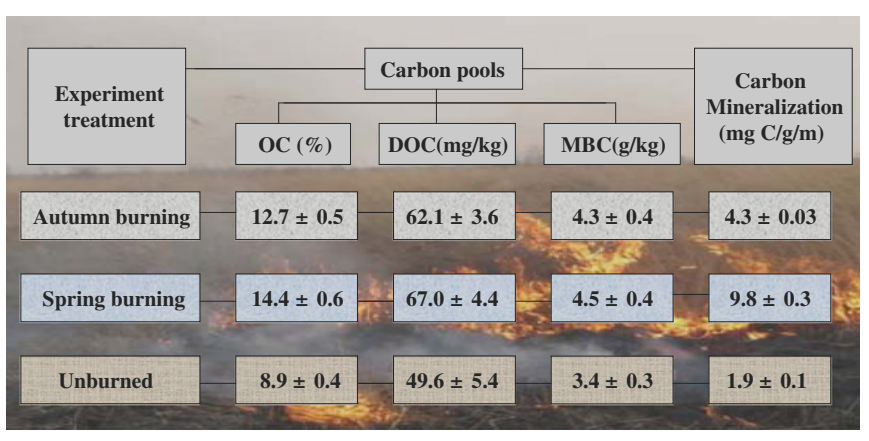

Fig. 9. Conceptual diagram of the effects of fire on various soil carbon pools and mineralization. Values represent means $\pm \operatorname{SE}(n=30)$.

plot allowed physical, chemical and biological processes to remove and/transform burning residues from the soils, which in turn controlled microbial growth. The combination of these factors would be responsible for the higher carbon mineralization in the soils in the spring than autumn burned plots.

\section{Conclusions}

Although it is well recognized that the effect of fire on soil carbon pool is significant (Fig. 9), its long term effect on wetland carbon remains uncertain, since previous studies were limited to a short period (one year or two). The results from our two-year field campaign reveal that the fire effect varies from one soil carbon form to another. Soil organic carbon $(\mathrm{OC})$ increased in the burned soils in both growing seasons, but the abundances of soil dissolved organic carbon (DOC) and microbial biomass carbon (MBC) increased in the first post-burning growing season and then returned to the pre-burning levels in the second growing season. The variability in soil MBC and DOC also depends on burning time (spring vs. autumn) and sampling time. In general, spring burnings exerted a larger effect than autumn burnings on soil carbon pool, due in part to the difference in soil water content and the lag between the burning and sampling time. Although the impact seems short-lived, the frequent reoccurrence of wildfires may extend the short-term effect to interfere with the longer-term carbon cycling within and outside the burn areas.

Compared to the unburned soils, the cumulative carbon mineralization data and carbon mineralization ratio in the burned soils were higher, and the spring fire had more significant influence on carbon mineralization than the autumn fire. Fires increased the microbial metabolism in the post-burning period, resulting in higher carbon losses from the ecosystem compared to undisturbed ecosystem. Therefore, fires increased $\mathrm{CO}_{2}$ emissions to the atmosphere not only during the combustion process, but also for an extended postburning period.

\section{Acknowledgment}

The authors thank Dr. Beth Middleton of U.S. Geological Survey for constructive comments on an earlier version of this manuscript, Yuxia Zhang, Haiyang Zhao, and Bokun Lou for conducting sample analyses, and Yang Wang for prescribed burning treatment. Assistance of the Sanjiang Mire Wetland Experimental Station, Chinese Academy of Sciences is also gratefully acknowledged. Financial support was provided by the National Basic Research Program of China (no. 2012CB956100), the Knowledge Innovation Program of Chinese Academy of Sciences (no. KZCX2-EW-319), and the National Natural Science Foundation of China (no. 40830535). Research also supported by the CAS/SAFEA International Partnership Program for Creative Research Teams (no. KZZD-EW-TZ-07).

\section{References}

Anderson, T.H., 2003. Microbial eco-physiological indicators to assess soil quality. Agriculture, Ecosystems and Environment 98, 285-293.

Andersson, M., Michelsen, A., Jensen, M., Kjøller, A., 2004. Tropical savannah woodland: effects of experimental fire on soil microorganisms and soil emission of carbon dioxide. Soil Biology and Biochemistry 36, 849-858.

Ansley, R.J., Boutton, T.W., Skjemstad, J.O., 2006. Soil organic carbon and black carbon storage and dynamics under different fire regimes in temperate mixed-grass savanna. Global Biogeochemical Cycles 20, GB3006, http://dx.doi.org/10.1029/ 2005GB002670.

Badía, D., Martí, C., 2003. Plant ash and heat intensity effects on chemical and physical properties of two contrasting soils. Arid Land Research Management 17, $23-41$.

Bremer, D.J., Ham, J.M., 2010. Net carbon fluxes over burned and unburned native tallgrass prairie. Rangeland Ecology and Management 63 (1), 72-81.

Bridgham, S.D., Updegraff, K., Pastor, J., 1998. Carbon, nitrogen, and phosphorus mineralization in northern wetlands. Ecology 79, 1545-1561.

Choromanska, U., DeLuca, T.H., 2002. Microbial activity and nitrogen mineralization in forest mineral soils following heating: evaluation of post-fire effects. Soil Bio Biochemistry 34, 263-271.

Clay, G.D., Worrall, F., Fraser, E.D.G., 2009. Effects of managed burning upon dissolved organic carbon (DOC) in soil water and runoff water following a managed burn of a UK blanket bog. Journal of Hydrology 367, 41-51.

Czimczik, C.I., Schmidt, M.W.I., Schulze, E.D., 2005. Effects of increasing fire frequency on back carbon and organic matter in Podzols of Siberian Scots pine forests. European Journal of Soil Science 56, 417-428.

Fernández, I., Cabaneiro, A., Carballas, T., 1999. Carbon mineralization dynamics in soils after wildfires in two Galician forests. Soil Biol Biochemistry 31, 1853-1865.

Fierror, A., Rutigliano, F.A., De Marco, A., Castaldi, S., De Santo, A.V., 2007. Post-fire stimulation of soil biogenic emission of $\mathrm{CO}_{2}$ in a sandy soil of a Mediterranean shrubland. International Journal of Wildland Fire 16 (5), 573-583.

Gu, B.H., Miao, S.L., Edelstein, C., Dreschel, T., 2008. Effects of a prescribed fire on dissolved inorganic carbon dynamics in a nutrient-enriched Everglades wetland. Fundamental and Applied Limnology 171, 263-272.

Gupta, S.R., Singh, J.S., 1981. Soil respiration in a tropical grassland. Soil Biol Biochemistry $13,261-268$.

Harris, W.N., Boutton, T.W., Ansley, R.J., 2008. Plant community and soil microbial carbon and nitrogen responses to fire and clipping in a southern mixed grassland. Rangeland Ecology and Management 61 (6), 580-587.

Hatten, J.A., Zabowski, D., 2009. Changes in soil organic matter pools and carbon mineralization as influenced by fire severity. Soil Science Society of America Journal 73, 262-273.

Hatten, J.A., Zabowski, D., Ogden, A., Thies, W., 2008. Soil organic matter in a ponderosa pine forest with varying seasons and intervals of prescribed burn. Forest Ecology and Management 255, 2555-2565.

Houghton, R.A., Hackler, J.L., Lawrence, K.T., 2000. Changes in terrestrial carbon storage in the United States. 2: The role of fire and fire management. Global Ecology and Biogeography 9, 145-170.

Jobbagy, E.G., Jackson, R.B., 2000. The vertical distribution of soil organic carbon and its relation to climate and vegetation. Ecological Applications 10 (2), 423-436.

Jokinen, H.K., Kiikkila”, O., Fritze, H., 2006. Exploring the mechanisms behind elevated microbial activity after wood ash application. Soil Biol Biochemistry 28, 2285-2291.

Jones, D.L., Willett, V.B., 2006. Experimental evaluation of methods to quality dissolved organic nitrogen (DON) and dissolved organic carbon (DOC) in soil. Soil Biol Biochemistry 38, 991-999.

Kara, O., Bolat, I., 2007. Impact of alkaline dust pollution on soil microbial biomass carbon. Turkish Journal of Agriculture and Forestry 31, 181-187.

Kara, O., Bolat, I., 2009. Short-term effects of wildfire on microbial biomass and abundance in black pine plantation soils in Turkey. Ecological Indicators 9, 1151-1155.

Kaye, J.P., Romanyà, J., Vallejo, V.R., 2010. Plant and soil carbon accumulation following fire in Mediterranean woodlands in Spain. Oecologia 164, 533-543.

Knapp, A.K., Conard, S.L., Blair, J.M., 1998. Determinants of soil $\mathrm{CO}_{2}$ flux from a subhumid grassland: effect of fire and fire history. Ecological Applications 8, 760-770.

Knicker, H., 2007. How does fire affects the nature and stability of soil organic nitrogen and carbon? A review. Biogeochemistry 85, 91-118.

Li, X.H., Wang, S.X., Duan, L., Hao, J.M., Li, C., Chen, Y.S., Yang, L., 2007. Particulate and trace gas emissions from open burning of wheat straw and corn stover in China. Environmental Science and Technology 41 (17), 6052-6058.

Liu, W.X., Xu, W.H., Hong, J.P., Wan, S.Q., 2010. Interannual variability of soil microbial biomass and respiration in responses to topography, annual burning and $\mathrm{N}$ addition in a semiarid temperate steppe. Geoderma 158 (3-4), 259-267.

Lu, R.K., 2000. Chemical Analysis Method of Agricultural Soil. China Agricultural Technology Press, Beijing. (in Chinese).

Monleon, V.J., Choromack, K., Landsberg, J.D., 1997. Short- and long-term effects of prescribed underburning on nitrogen availability in ponderosa pine stands in central Oregon. Canadian Forest Research 27 (3), 369-378.

Oluwole, F.A., Sambo, J.M., Sikhalazo, D., 2008. Long-term effects of different burning frequencies on the dry savannah grassland in South Africa. African Journal of Agricultural Research 3 (2), 147-153.

Palese, A.M., Giovannini, G., Lucchesi, S., Dumontet, S., Perucci, P., 2004. Effect of fire on soil C, N and microbial biomass. Agronomie 24, 47-53.

Pardini, G., Gispert, M., Dunjó, G., 2004. Relative influence of wildfire on soil properties and erosion processes in different Mediterranean environments in NE Spain. Science of the Total Environment 328, 237-246.

Qian, Y., Miao, S.L., Gu, B., Li, Y.C., 2009. Estimation of postfire nutrient loss in the Florida Everglades. Journal of Environmental Quality 38, 812-820. 
Rutigliano, F.A., De Marco, A., D'Ascoli, R., Castaldi, S., Gentile, A., De Santo, A.V., 2007. Impact of fire on fungal abundance and microbial efficiency in C assimilation and mineralization in a Mediterranean maquis soil. Biology and Fertility of Soils 44 (2), 37-381.

Shibata, H., Petrone, K.C., Hinzman, L.D., Boone, R.D., 2003. Effect of fire on dissolved organic carbon and inorganic solutes in spruce forest in the Permafrost Region of Interior Alaska. Soil Science \& Plant Nutrition 49 (1), 25-29.

Smith, L.M. 1983. Effects of prescribed burning on the ecology of a Utah Marsh. Ph.D. thesis, Fisheries \& Wildlife Ecology, Utah State University. Logan, Utah.

Snyman, H.A., 2003. Short-term response of rangeland following an unplanned fire in terms of soil characteristics in a semi-arid climate of South Africa. Journal of Arid Environments 55, 160-180.

van der Werf, G.R., Randerson, J.T., Giglio, L., Collatz, G.J., Kasibhatla, P.S., Arellano, A.F. 2006. Interannual variability in global biomass burning emissions from 1997 to 2004. Atmospheric Chemistry and Physics 6, 3423-3441.

Vance, E.D., Brookes, P.C., Jenkinson, D.S., 1987. An extraction method for measuring soil microbial biomass C. Soil Biol Biochemistry 19, 703-707.

Wang, A.H., Zhang, S.Q., He, Y.F., 2002. Study of dynamic change of mire in Sanjiang Plain based on RS and GIS. Scientia Geographica Sinica 22 (5), 636-640 (in Chinese with English Abstract.).

Wang, G.P., Liu, J.S., Wang, J.D., Yu, J.B., 2006. Soil phosphorus forms and their variations in depressional and riparian freshwater wetlands (Sanjiang Plain, Northeast China). Geoderma 132, 59-74.
Ward, S.E., Bardgett, R.D., McNamara, N.P., Adamson, J.K., Ostle, N.J., 2007. Long-term consequences of grazing and burning on northern peatland carbon dynamics. Ecosystems $10,1069-1083$.

Westerling, A.L., Betancourt, J.L., Schwartz, M.D., 2007. Reevaluation of the spring onset/fire association in the western U.S. using phenological vs. hydrological models. Proceedings of the American Geophysical Union 2007 Fall Meeting.

Wiedinymer, C., Quayle, B., Geron, C., Belote, A., Mckenzie, D., Zhang, X., O'Neill, S., Wynne, K.K., 2006. Estimating emissions from fires in North America for air quality modeling. Atmospheric Environment 40, 3419-3432.

Yang, J.S. 2006. Study on dynamics of organic carbon of Deyeuxia angutifolia wetland ecosystem in Sanjiang Plain. Ph.D. thesis. Graduate School of Chinese Academy of Sciences, Northeast Institute of Geography and Agricultural Ecology. Changchun, China.

Zhang, J., Song, C., Wang, S., 2007. Dynamics of soil organic carbon and its fractions after abandonment of cultivated wetlands in northeast China. Soil \& Tillage Research 96, 350-360.

Zhao, K.Y., 1999. Mire Record of China. Science Press, Beijing. 120 pp.

Zhao, H.M., Bao, K.S., Yu, X.F., Wang, J., Lu, X.G., Wang, G.P., 2010. Plant ash also contributes dissolved organic matter to the environments: a case study of Sanjiang Plain wetlands. Fresenius Environmental Bulletin 19 (11), 2518-2522.

Zhou, Z.Q., 2005. Vegetation and Plant Resources of Sanjiang Plain. Northeast Forestry University Press, Harbin. 